\title{
Strong founder effect for a transglutaminase 1 gene mutation in lamellar ichthyosis and congenital ichthyosiform erythroderma from Norway
}

\author{
M aritta Pigg ${ }^{1,2}$, Tobias G edde-D ahl I $r^{3}$, D iane Cox ${ }^{4}$, Ingrid H außer ${ }^{5}$, Ingrun \\ A nton-L amprecht ${ }^{5}$ and Niklas D ahl ${ }^{1}$ \\ ${ }^{1} U$ nit of Clinical G enetics, D epartment of G enetics and Pathology, University H ospital, Uppsala, Sweden \\ ${ }^{2} U$ nit of D ermatology and Venerology, D epartment of M edical Sciences, U niversity H ospital, U ppsala, Sweden \\ ${ }^{3}$ D ermatological D NA L aboratory, D epartment of D ermatology, and Institute of Forensic M edicine, Rikshospitalet \\ and University of $\mathrm{O}$ slo, N orway \\ ${ }^{4} \mathrm{D}$ epartment of M edical G enetics, $670 \mathrm{H}$ eritage M edical Research Centre, University of A lberta, E dmonton, Canada \\ ${ }^{5}$ Institute of U Itrastructure R esearch of the Skin, D epartment of D ermatology, U niversity of H eidelberg, G ermany
}

\begin{abstract}
Autosomal recessive congenital ichtyosis (ARCI) is a clinically heterogeneous disorder of keratinisation. It was recently shown that mutations in the transglutaminase 1 (TGM1) gene may be associated with the clinical subtypes lamellar ichthyosis (LI) and non-bullous congenital ichthyosiform erythroderma (CIE). Thirty-six Norwegian families with LI and seven with non-bullous CIE were studied with microsatellite markers linked to the TGMI gene. One common halpotype for two markers was found on $74 \%$ of disease associated chromosomes. Three individuals homozygous for the common haplotype, two affected by $\mathrm{LI}$ and one affected by CIE, were analysed for mutations in the TGM1 gene. All three patients were found homozygous for a single $A$ to $G$ transition located in the canonical splice acceptor site of intron 5. Probands from the remaining 40 families with $\mathrm{LI}$ and CIE were screened for this mutation and the A to $G$ transition was found on 61 out of 72 alleles associated with LI and on 9 out of 15 alleles associated with CIE. These findings suggest a single founder mutation for the majority of patients with LI and CIE in Norway. The $2526 \mathrm{~A} \rightarrow \mathrm{G}$ mutation results in the insertion of a guanosine at position 877 (876insG) in the mature cDNA and the frame shift creates a premature termination at codon 293. The mutation was previously observed in one family with a resulting CDNA that included the entire intron 5 . These results suggest that the mutation can result in variant transcripts in different individuals.
\end{abstract}

Keywords: lamellar ichthyosis; non-bullous congenital ichthyosiform erythroderma; transglutaminase 1 (TGM1) gene; founder effect

Correspondence: M aritta Pigg or Nikas D ahl, U nit of Clinical G enetics, D epartment of $G$ enetics and Pathology, U niversity H ospital, S-751 85 U ppsala, Sweden. Tel: + 46-18-662799; Fax: +46-18-554025; E-mail: maritta.pigg@klingen.uu.se or niklas.dahl@klingen.uu.se

R eceived 10 December 1997; revised 2 A pril 1998; accepted 15 A pril 1998 


\section{Introduction}

A utosomal recessive congenital ichthyosis $(\mathrm{A} \mathrm{Cl})$ is a heterogeneous group of inherited disorders ${ }^{1}$ that affect the keratinisation process in the skin. L amellar ichthyosis (LI) and nonbullous congenital ichthyosiform erythroderma $(\mathrm{CIE})$ are two clinical $\mathrm{ARCl}$ subtypes characterised by scaling of the skin. The patients can be born as collodion babies, a membrane which covers the entire body and which cracks after a few days. E verted lips (eclabium) and everted eyelids (ectropion) can be seen in a proportion of the cases. ${ }^{2,3}$ The subtype CIE presents with erythroderma and fine white scaling of the skin, whilst LI presents without or with minimal erythroderma and with dark, platelike scales covering the body. ${ }^{1,3-5}$ Autosomal recessive ichthyosis (MIM no.242300) can also be classified into four subgroups (type I-IV) based on electron microscopic (EM) features of epidermis. ${ }^{5-7} \mathrm{~A}$ ccording to this classification CIE corresponds to EM type I and LI corresponds to EM type II, respectively.

Linkage analysis has localised the gene for $L I$ to chromosome $14 \mathrm{q} 11^{8}$ and close to the epidermal transglutaminase 1 (TG M 1) gene locus. ${ }^{9-11}$ Sequence analysis of $L I$ patients revealed mutations in the TG M 1 gene associated with the disease. ${ }^{12-17}$ Transglutaminase 1 is an enzyme which is active during terminal differentiation of keratinocytes and is important for the formation of the cornified envelope by a cross-linking reaction of precursor proteins such as loricrin and involucrin. However, a normal transglutaminase activity and a normal TG M 1 gene sequence were found in a proportion of patients with $\mathrm{LI}$ indicating genetic heterogeneity. ${ }^{14,18}$ This was previously suggested from the ultrastructure analysis of skin biopsies ${ }^{6,7}$ and recently confirmed by the identification of a second locus for $\mathrm{LI}$ on chromosome $2 q .{ }^{19}$ There is evidence of yet a third locus for $\mathrm{LI}$ in some families linked to neither TGM 1 nor chromosome 2q.

We present here the combined results from clinical, ultrastructural, and molecular analyses of 43 Norwegian families affected by LI or CIE. The study included clinical examinations, electron microscopy of skin biopsies, analyses with microsatellite markers linked to the TGM 1 gene, and mutation analysis of the TGM 1 gene.

\section{Materials and Methods}

\section{Patients and Families}

Forty-three Norwegian families comprising 55 members affected by congenital (1st day) onset of LI or CIE were studied. Patients were identified from the past 27 years and blood samples were collected. The patients were examined clinically by one of the authors (TG -D) with the exception of two cases that were examined by local dermatologists (Table 1). A family history of collodion skin supported the diagnosis but this was not taken as a mandatory criterion. $\mathrm{N}$ ine patients were clinically evaluated after systemic retinoid treatment had been started. Skin biopsy samples from various body sites (gluteal region, back, upper arm) were prepared for transmission EM. The ultrastructural evaluation (Figure 1, Table 1 ) was performed by two of the authors (IA - $L$ and IH). In eight families EM evaluation was not performed and the diagnosis was based on the clinical evaluation alone. ${ }^{4}$ The geographical origin of the parents of affected individuals was determined. G enealogical investigations identified a common ancestry of four families from West N orway and also of two families in an isolated valley of $E$ ast N orway. O ne parent was an immigrant from G ermany. The study was approved by the E thical Committee of U ppsala U niversity, Sweden.

\section{DNA Samples and Haplotype Analysis}

Genomic DNA was extracted from peripheral blood cells with phenol-chloroform ${ }^{20}$ or by the salt extraction method. ${ }^{21}$ Highly polymorphic DNA markers assigned to chromosome 14q11, and linked to the TGM 1 locus, were used for allelic association and for haplotype analysis. The polymorphic dinucleotide repeat markers D14S64, D 14S264, and $\mathrm{D} 14 \mathrm{~S} 275^{22}$ were analysed by radioactivity as described for other microsatellite markers. ${ }^{23}$ The intragenic TGM 1 intron 14 dinucleotide repeat ${ }^{10}$ was typed and visualised by flourescent labelling using an A BI automatic sequencer according to Dupuy and Olaisen. ${ }^{24}$ The allele frequencies for the markers used were determined in the Norwegian population. The number of control chromosomes were 304, 96, 101 and 104 for the markers T G M 1 intron 14, D 14S64, D 14S264, and D 14S275, respectively. The test for pairwise allelic association was determined by the chi-square method.

\section{cDNA Synthesis and Sequencing}

The entire protein coding region of the TGM 1 gene was sequenced from cDNA (exon 2-9) and from genomic DNA (exon 10-15).

Skin fibroblast cultures were established from three patients, one affected by CIE (IR 26) and two affected by LI (IR 1 and IR 13, Table 1). Total RNA was extracted either immediately after harvest or after the cells had been stored at $-70^{\circ} \mathrm{C}$ in guanidinium thiocyanate. ${ }^{25}$ For reverse transcription (RT), approximately $5 \mu \mathrm{g}$ of total RNA was used in the presence of 5 pmol primer (5'-GAA CTC CCT GGA TGA CA A TG ) specific for the TGM 1 mR NA. A fter a denaturation step at $70^{\circ} \mathrm{C}$ for $10 \mathrm{~min}$, the $\mathrm{RT}$ reaction was performed in a total volume of $20 \mu 1$ with 2.5 units of A MV reverse transcriptase (Pharmacia Biotech, U ppsala, Sweden), 0.03 units of RNA se inhibitor (RNA guard, Pharmacia Biotech, U ppsala, Sweden), $10 \mathrm{~mm}$ Tris (pH 8.3), $5 \mathrm{~mm} \mathrm{M} \mathrm{gCl}, 1 \mathrm{~mm}$ of each deoxynucleotide triphosphate (dNTP) and incubated at $42^{\circ} \mathrm{C}$ for $1 \mathrm{~h}$ followed by $70^{\circ} \mathrm{C}$ for $10 \mathrm{~min}$. The $\mathrm{RT}$ reaction was followed by PCR performed with three different sets of primer pairs. The three resulting amplicons corresponded to nt (-44)- 568, nt 454-1136 and nt 985-1646, respectively, of the T G M 1 CDNA (G enB ank accession number M 90287). The PCR $\left(94^{\circ}, 1 \mathrm{~min} ; 63^{\circ}, 1 \mathrm{~min} ; 72^{\circ}, 2.5 \mathrm{~min}\right)$ was performed in a total volume of $40 \mu$ l using $5 \mu 1$ of the RT reaction, $200 \mathrm{~mm}$ of 
each dNTP, $1.5 \mathrm{~mm} \mathrm{MgCl}_{2}, 2$ units of Taq polymerase and $0.1 \mathrm{~mm}$ of each primer and run for 25 cycles. Nested PCR was performed with three internal sets of primers in a total volume of $100 \mu \mathrm{l}$ with $|\mu|$ of the corresponding RT-PCR reaction diluted 100-500 times. Primers used for the sequencing reactions were the same as used for nested PCR. Two amplicons containing exons 10-14 and exon 15, respectively, were generated by PCR using genomic DNA from the three patients. The fragment containing exons 10-14 was amplified using primers 5'-CTG GGG CCT GTG TGG ACC TTA C and $5^{\prime}-T G G$ GGA AGG CCA GAG TGG AAG CA, and exon 15 using primers 5'-A GC TCT TAC TCC CCA CTC CAC and 5'-GGC TCC ATC CGT CTT GGT GTG. A fragment corresponding to exon 5 , intron 5 and exon 6 of the

Table 1 R esults of clinical and ultrastructural evaluation, haplotyping and mutation analysis in LI and CIE patients from Norway

\begin{tabular}{|c|c|c|c|c|c|c|c|}
\hline \multirow[b]{2}{*}{ Proband } & \multirow[b]{2}{*}{ Status } & \multirow[b]{2}{*}{ EM } & \multicolumn{4}{|c|}{ M arker alleles } & \multirow[b]{2}{*}{ M utations } \\
\hline & & & TGM 1 & D 14S64 & D 14S264 & D 14S275 & \\
\hline IR 1 & L 1 & 2 & $5 / 5$ & $2 / 2$ & $5 / 5$ & $2 / 2$ & A 2526G /A 2526G \\
\hline $\operatorname{IR~} 2$ & $\mathrm{LI}$ & $\mathrm{U}$ & $5 / 5$ & $2 / 2$ & $5 / 0$ & $4 / 2$ & A 2526G /A 2526G \\
\hline IR 3 & LI (R et.) & $\mathrm{Nt}$ & $5 / 5$ & $3 / 1$ & $1 / 4$ & $3 / 1$ & $-1-$ \\
\hline IR 4 & $\mathrm{LI}$ & 2 & $5 / 5$ & $2 / 2$ & $3 / 5$ & $5 / 4$ & A 2526G /A 2526G \\
\hline IR 5 & LI & 2 & $5 / 5$ & $2 / 2$ & $5 / 4$ & $2 / 4$ & A 2526G /A 2526G \\
\hline IR 6 & CIE (R et.) & 1 & $5 / 5$ & $2 / 3$ & $5 / 4$ & $4 / 2$ & A $2526 \mathrm{G} /-$ \\
\hline IR 7 & LI & $\mathrm{Nt}$ & $5 / 5$ & $3 / 3$ & $4 / 5$ & $2 / 4$ & $-1-$ \\
\hline IR 9 & Ll & U & $5 / 5$ & $2 / 2$ & $4 / 4$ & $1 / 3$ & A 2526G /A 2526G \\
\hline IR 12 & $\mathrm{LI}$ & 2 & $5 / 5$ & $2 / 3$ & $4 / 4$ & $1 / 3$ & A 2526G /A 2526G \\
\hline IR 13 & $\mathrm{LI}$ & 2 & $5 / 5$ & $2 / 2$ & $5 / 5$ & $2 / 2$ & A 2526G /A 2526G \\
\hline IR 19 & LI & 2 & $5 / 5$ & $2 / 2$ & $5 / 5$ & $3 / 4$ & A 2526G /A 2526G \\
\hline IR 20 & $\mathrm{LI}$ & 2 & $5 / 5$ & $2 / 2$ & $3 / 3$ & $4 / 5$ & A 2526G /A 2526G \\
\hline IR 24 & LI & 2 & $5 / 5$ & $2 / 2$ & $4 / 5$ & $5 / 3$ & A 2526G /A 2526G \\
\hline IR 25 & LI & $\mathrm{Nt}$ & $5 / 5$ & $2 / 2$ & $5 / 5$ & $2 / 2$ & A 2526G /A 2526G \\
\hline IR 26 & $\mathrm{CIE}$ & U & $5 / 5$ & $2 / 2$ & $5 / 5$ & $2 / 2$ & A 2526G /A 2526G \\
\hline IR 27 & LI & 2 & $7 / 5$ & $3 / 2$ & $1 / 5$ & $5 / 2$ & $-/ A 2526 G$ \\
\hline IR 31 & LI & $\mathrm{Nt}$ & $5 / 5$ & $2 / 2$ & $3 / 5$ & $4 / 3$ & A 2526G /A 2526G \\
\hline IR 32 & LI & 2 & $5 / 5$ & $2 / 2$ & $4 / 10^{i+}$ & $4 / 5$ & A 2526G /A 2526G \\
\hline IR 33 & LI & 2 & $5 / 5$ & $2 / 2$ & $5 / 5$ & $2 / 3$ & A 2526G /A 2526G \\
\hline IR 37 & LI (R et.) & 2 & $5 / 5$ & $3 / 3$ & $2 / 7$ & $5 / 5$ & $-1-$ \\
\hline IR 39 & LI & 2 & $5 / 5$ & $2 / 2$ & $3 / 3$ & $3 / 4$ & A 2526G /A 2526G \\
\hline IR 40 & $\mathrm{CIE}$ & $\overline{1}$ & $5 / 5$ & $2 / 2$ & $3 / 4$ & 5.4 & A 2526G /A 2526G \\
\hline IR 42 & LI & 2 & $5 / 5$ & $2 / 2$ & $5 / 5$ & $3 / 3$ & A 2526G /A 2526G \\
\hline IR 43 & $\mathrm{LI}$ & $\mathrm{Nt}$ & $5 / 5$ & $2 / 2$ & $5 / 5$ & $3 / 3$ & A 2526G /A 2526G \\
\hline IR 44 & $\mathrm{LI}$ & $\mathrm{Nt}$ & $5 / 5$ & $3 / 3$ & $2 / 2$ & $4 / 4$ & $-1-$ \\
\hline IR 45 & LI & $\mathrm{Nt}$ & $5 / 5$ & $2 / 2$ & $5 / 5$ & $4 / 2$ & A 2526G /A 2526G \\
\hline IR 46 & LI & U & $5 / 5$ & $-1^{\mathrm{ii} / 2}$ & $5 / 5$ & $5 / 2$ & A 2526G /A 2526G \\
\hline IR 49 & LI & 2 & $5 / 5$ & $2 / 4$ & $3 / 0$ & $2 / 4$ & A 2526G /A 2526G \\
\hline IR 51;1 & $\mathrm{CIE}$ (R et.) & 1 & $5 / 5$ & $3 / 3$ & $3 / 3$ & $1 / 3$ & $-1-$ \\
\hline IR $51 ; 2$ & CIE (R et.) & 1 & $1 / 5$ & $3 / 3$ & $3 / 3$ & $1 / 3$ & $-1-$ \\
\hline IR 52 & LI (R et.) & U & $5 / 5$ & $2 / 2$ & $5 / 5$ & $2 / 2$ & A 2526G /A 2526G \\
\hline IR 58 & LI (R et.) & 2 & $5 / 5$ & $2 / 2$ & $3 / 5$ & $4 / 5$ & A 2526G /A 2526G \\
\hline IR 59 & $\mathrm{ClE}^{*}$ & 2 & $1 / 5$ & $3 / 3$ & $4 / 4$ & $4 / 2$ & $-1-$ \\
\hline IR 62 & LI & 2 & $5 \# 5$ & $1 \# 3$ & $4 \# 3$ & $5 \# 2$ & -\#A 22526G \\
\hline IR 68 & $\mathrm{LI}$ & 2 & $5 / 5$ & $2 / 2$ & $5 / 4$ & $2 / 4$ & A 2526G /A 2526G \\
\hline IR 70 & LI & 2 & $5 / 5$ & $2 / 2$ & $5 / 5$ & $2 / 4$ & A 2526G /A 2526G \\
\hline IR 74 & CIE (R et.) & 1 & 5.5 & $2 / 5$ & $3 / 4$ & $4 / 5$ & A 2526G /A 2526G \\
\hline IR 75 & LI & 2 & $5 / 5$ & $2 / 2$ & $5 / 3$ & $2 / 4$ & A 2526G /A 2526G \\
\hline IR 76 & LI & 2 & $5 / 5$ & $9 \mathrm{iii}+/ 3$ & $3 / 4$ & $4 / 2$ & A $2526 \mathrm{G} /-$ \\
\hline IR 77 & LI & 2 & $5 / 5$ & $2 / 2$ & $3 / 3$ & $5 / 5$ & A 2526G /A 2526G \\
\hline IR 92 & $\mathrm{CIE}^{*}$ & 2 & $5 / 5$ & $2 / 2$ & $3 / 5$ & $2 / 5$ & A 2526G /A 2526G \\
\hline IR 93 & LI† (R et.) & 2 & $5 / 5$ & $2 / 2$ & $3 / 3$ & $3 / 4$ & A 2526G /A 2526G \\
\hline IR 94 & $\mathrm{LI}^{\dagger}$ & $\mathrm{Nt}$ & $5 / 5$ & $2 / 3$ & $5 / 5$ & $2 / 5$ & A 2526G /A 2526G \\
\hline IR 95 & LI & 2 & $5 / 5$ & $2 / 2$ & $\mathrm{Nt} / \mathrm{Nt}$ & $\mathrm{Nt} / \mathrm{Nt}$ & A 2526G /A 2526G \\
\hline
\end{tabular}

( $R$ et.) retinoic acid treatment by the time of diagnosis and biopsy taken for $E M$.

$\mathrm{U}$ : unspecific. $\mathrm{Nt}$ : not typed. ${ }^{*} \mathrm{CIE}$ phenotypes as infants, but bordering LI phenotypes with age. t: examined by local dermatologists. \#. G erman haplotype. i: de novo mutation in D 14S264, paternal or maternal $4 \rightarrow 5$ mutation. ii: inherited or new mutation. iii: paternal de novo mutation. +: non-paternity was ruled out. /: parental origin. 


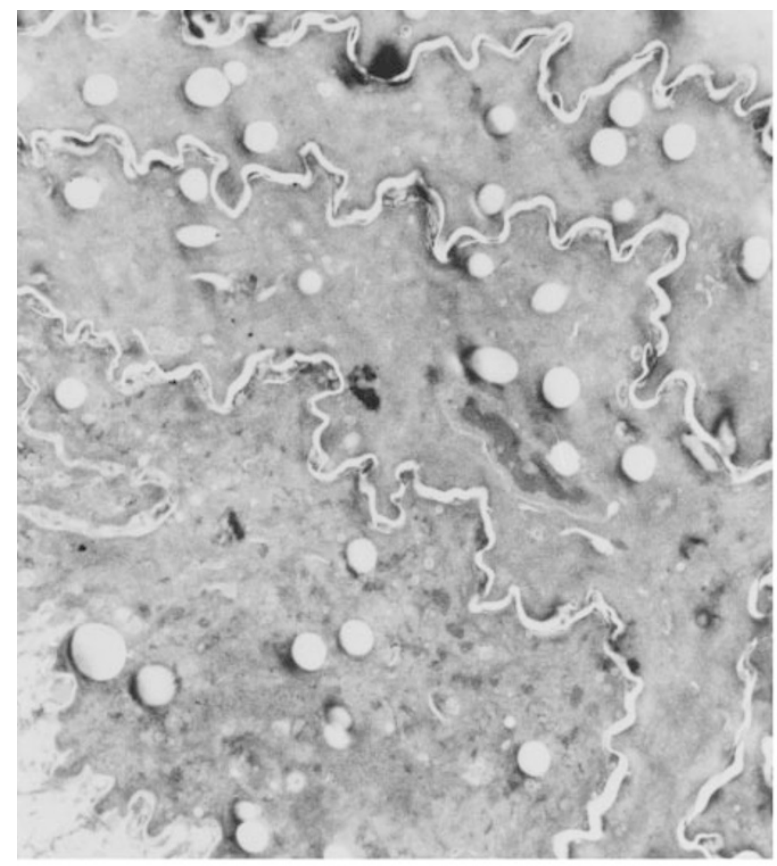

A

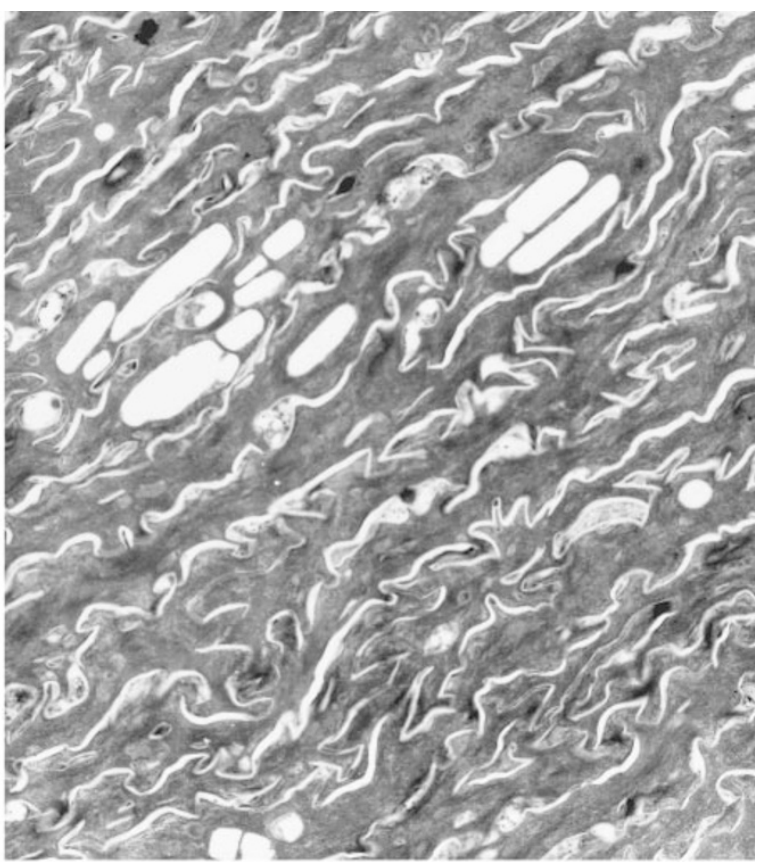

B

Figure 1 Ultrastructural features of skin biopsies (magnification approximately $\times 9500$ ) from A a patient with CIE, E M type I and from B a patient with LI, EM type II. EM type I is characterised by a compact hyperkeratotic horny layer with numerous lipid vacuoles. E M type II is characterised by a massive compact hyperkeratotic horny layer with groups of electron-lucent clefts presenting remnants of cholesterol crystals as a significant diagnostic marker.

TGM 1 gene (nt 2234-2640; GenBank accession number $M$ 86360) was amplified in order to confirm the results from the $\mathrm{CDNA}$ sequencing. Cycle sequencing was performed on amplicons derived from CDNA and genomic DNA after gel purification on a $1 \%$ low melting point agarose gel (Sea plaque, FMC BioProducts, ME, USA). The gel slices were treated with agarase (Boeringer $\mathrm{M}$ annheim $\mathrm{GmbH}, \mathrm{M}$ annheim, Germany) following the manufacturers' protocol. Cycle sequencing was performed with the Dye Terminator Cycle Sequencing Core K it (Perkin EImer, CA, USA) and analysed on an automated A BI 373 DNA Sequencer.

\section{Restriction Enzyme Analysis}

The $A$ to $G$ mutation found in intron 5 creates a new restriction site for $\mathrm{Mspl}$ on genomic DNA. The presence of the new restriction site was analysed in all 43 families including 55 patients with LI or CIE. A 150 bp DNA fragment spanning the mutation was amplified using primers 5 '-G GC TGG GGT ATT GGA GCA GG (forward), and 5'-TGG GTC TCC ACG GCC TCC AT (reverse). The PCR reaction $\left(94^{\circ}, 30 \mathrm{~s} ; 63^{\circ}, 30 \mathrm{~s} ; 72^{\circ}, 30 \mathrm{~s}\right)$ was run for 30 cycles in a total volume of $100 \mu \mathrm{l}$. Restriction enzyme digestion of the PCR fragments was performed in a total volume of $30 \mu \mathrm{l}$ with 30 units of $\mathrm{Mspl}$ ( $\mathrm{New}$ England Biolabs, MA, USA) and the buffer supplied. The resulting fragments were separated by electrophoresis on a $12 \%$ polyacrylamide gel and visualised by ethidium bromide.

\section{Results}

Electron Microscopy (EM)

$\mathrm{U}$ Itrastructural diagnosis by $\mathrm{EM}^{7}$ was performed on dermal specimens from 35 families. The skin biopsy samples were from various body sites including the gluteal region, back and upper arm. Patients from 26 families showed the EM features of type II and patients from four families were classified as EM type I (Figure 1; Table 1). In five families the ultrastructural morphology was unspecific and did not permit EM classification and in eight families biopsies were not taken.

The correlation between the clinical classification and $\mathrm{EM}$ classification was consistent except in two cases where the patients initially had CIE phenotypes but bordered on LI phenotypes with age (IR 59 and IR 92, Table 1).

\section{Allelic Association and Haplotype Analysis} $\mathrm{H}$ aplotypes over the TGM 1 locus at chromosome $14 q 11$ were constructed with the microsatellite markers D 14S64, D 14S264, D 14S275 ${ }^{22}$ and the STR marker 
Table 2 Marker alleles around the TGM 1 gene in 43 N orwegian families with LI and CIE. Shaded area shows the haplotypes associated with the $2526 \mathrm{~A} \rightarrow \mathrm{G}$ mutation

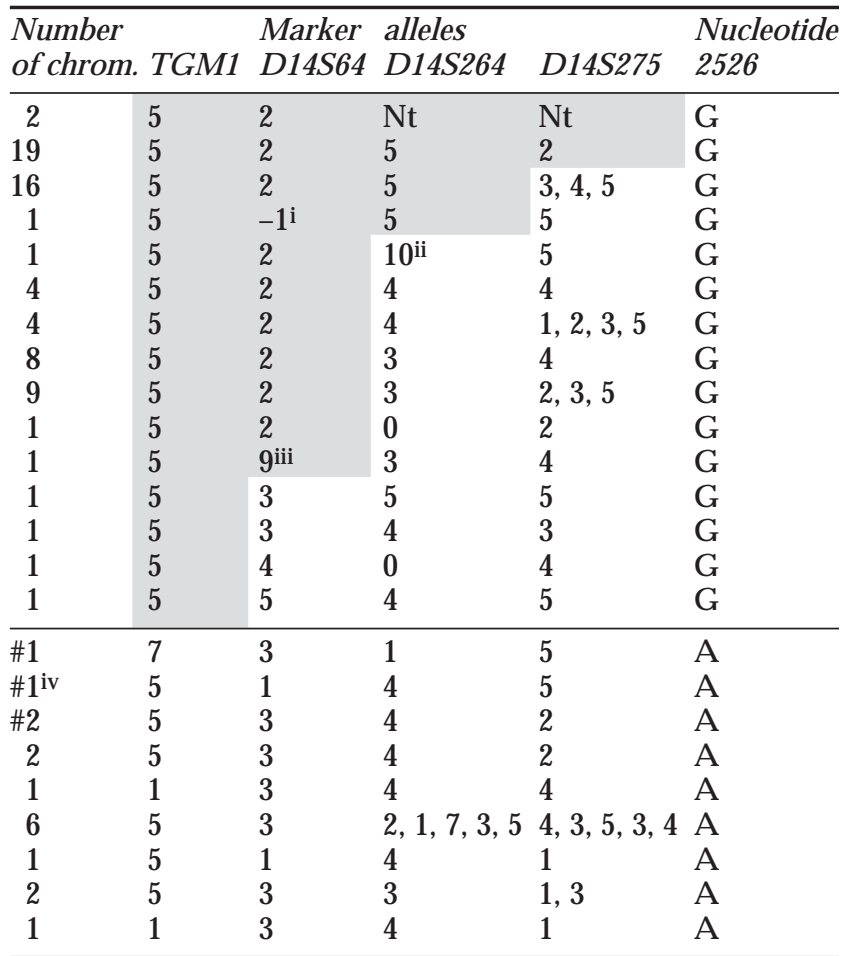

\#. haplotypes in patients heterozygous for the $2626 \mathrm{~A} \rightarrow \mathrm{G}$ mutation. $\mathrm{Nt}$ t: not typed. i: inherited or new mutation. ii: de novo mutation. iii: paternal de novo mutation. iv: German haplotype.

within the TGM 1 gene. ${ }^{10}$ The markers span $4.2 \mathrm{~cm}$ and their order from the centromere is (TGM 1/ D 14S64/D 14S264), D 14S275., ${ }^{8,22}$ The haplotypes found in the $\mathrm{LI}$ and CIE patients are presented in (Table 2). A common haplotype (5-2-5) was identified for the three markers TGM 1, D 14S64 and D 14S264 on 35 out of 87 chromosomes $(37 \%)$ associated with $\mathrm{LI}$ and $\mathrm{CIE}$, versus two out of $90(2 \%)$ on control chromosomes. The chi-square test revealed a significant association between the allele 5 (177 bp) at the TGM 1 intron 14 marker locus and LI/CIE $\left(P<10^{-6}\right)$, between D 14 S64 allele $2(131 \mathrm{bP})$ and $\mathrm{LI} / \mathrm{CIE}\left(\mathrm{P}<10^{-6}\right)$, and between D 145264 allele 5 ( $243 \mathrm{bp})$ and LI/CIE $\left(\mathrm{P}<1.5 \times 10^{-4}\right)$, respectively. In contrast, no associations were found between the corresponding pairs of loci among N orwegian control chromosomes. The combined results from allele association tests and haplotypes of $\mathrm{LI} / \mathrm{CIE}$ chromosomes suggest a founder effect for a TGM 1 mutation. The results also support the locations of the three anonymous markers D 14S64, D14S264 and D 14S275 on the same side of the TGM 1 gene in the order 14qcen-TG M 1-D 14S64-D 14S264-D 14S275-tel.

\section{Sequence Analysis of the TGM1 Gene and the TGM1 cDNA}

$D$ irect sequencing was performed on CDNA and genomic D NA from three non-related individuals, one affected by CIE (IR 26) and two affected by LI (IR 1 and IR 13, Table 1 ). The patients were homozygous for the haplotype 5-2-5 (TG M 1, D 14S64, D 14S264) associated with LI/CIE in the population studied. Sequencing of TGM 1-specific CD NA revealed homozygosity for an insertion of guanosine at position 877 (876insG). The results were verified on genomic DNA of the three patients and revealed a homozygous $2526 \mathrm{~A} \rightarrow \mathrm{G}$ transition (Figure 2) located in the canonical acceptor splice site of intron 5. The CDNA analysis shows that the mutation results in an alternate splicing with the guanosine at position 2526 of intron 5 retained in the spliced transcript. A s a consequence, the reading frame is altered and a premature stop codon (UGA) is created at codon 293. Sequencing of the entire protein coding region of the TGM 1 gene in the three patients revealed no other sequence alteration resulting in amino acid substitutions.

\section{Genotyping}

The A to $G$ mutation in intron 5 creates a new recognition site for $\mathrm{Mspl}$ at the genomic level (Figure 3). A PCR fragment spanning the transition was generated from genomic DNA of probands from all 43 families. The resulting amplicon was digested with $\mathrm{M} \mathrm{spl}$ and the $2526 \mathrm{~A} \rightarrow \mathrm{G}$ mutation was found to be present in 37 out of the 43 probands. In 33 families the affected individuals were homozygous for the mutation and in the remaining four families the patients were heterozygous (Table 1). No clinical differentation could be made on the basis of homozygosity or heterozygosity for the mutation. The transition accounts for $80 \%$ (70 out of 87) of $\mathrm{LI}$ and $\mathrm{CIE}$ alleles in the Norwegian population studied (Figure 4). The mutation was absent in two CIE and four LI families, none of which carried the common haploptype 5-2-5 (TGM 1D 14S64-D 14S264). There was no strong correlation between the clinical/EM classification and the molecular findings (Table 1 ). Five patients with $\mathrm{CIE}$ and 32 patients with LI were found to have the specific mutation.

\section{Discussion}

In this study we show that a single mutation in the TGM 1 gene is responsible for the majority of patients 
with $\mathrm{LI}$ and $\mathrm{CIE}$ in the Norwegian population. The $2526 \mathrm{~A} \rightarrow \mathrm{G}$ transition was present on $80 \%$ of alleles. $G$ enealogical investigations revealed common ancestors in only a few families and consanguinity over the
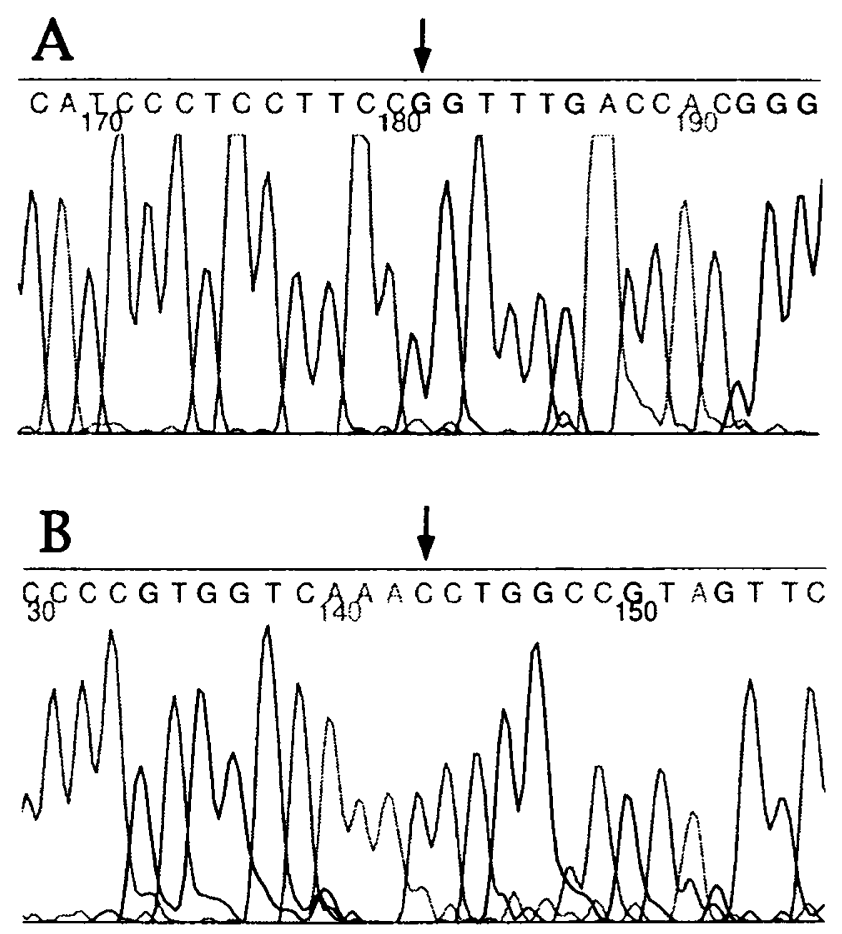

C

Exon 5 Intron 5

Exon 6

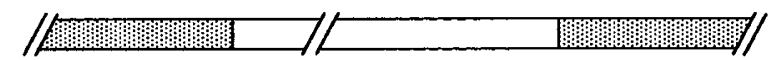

5'. TAC GGC CAG GTA....CC TCC TTC CGG TIT GAC CAC..3'

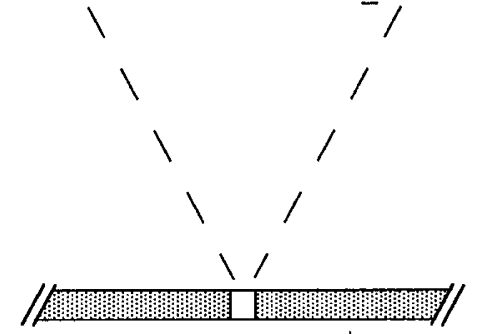

5'. TAC GGC CAG GTT TGA*CCA C..3'

Figure 2 A P rint-out from automated sequencing of genomic $D N A$ showing the $2526 \mathrm{~A} \rightarrow \mathrm{G}$ mutation (arrow) in a homozygous state and $\mathbf{B}$ the cDNA sequence (sequenced by a reverse reaction) with the insertion of a $G(C)$ at position 877 (arrow). C Schematic presentation of part of the TGM 1 gene (upper bar) with the resulting CDNA (bottom bar) in patients with the $2526 \mathrm{~A} \rightarrow \mathrm{G}$ mutation. The transition is underlined (top) and the position of the inserted guanosine in the CD NA is indicated in bold. The resulting frame shift is shown (bottom) and the stop codon is asterisked. last four generations was excluded in the majority of the families. However, the occurrence of a single ancestral mutation was supported by allelic association and by haplotype analysis. A II 70 chromosomes with the $2526 \mathrm{~A} \rightarrow \mathrm{G}$ mutation carried the same allele at the dinucleotide repeat in intron 14 of the TG M 1 gene. A $t$ the neighbouring locus D 14S64, 64 out of 70 mutant chromosomes shared one allele, whereas 37 chromosomes shared one allele at D 14S264. The more distal marker D14S275 showed a weaker association with only 20 chromosomes carrying $2526 \mathrm{~A} \rightarrow \mathrm{G}$ and a common allele. The results suggest ancestral recombinations between the different STR loci and the TGM 1 gene. The degree of association for marker alleles with the $2526 \mathrm{~A} \rightarrow \mathrm{G}$ mutation and the haplotypes constructed favours the relative order 14qcen-TGM 1D 14S64-D 14S264-D 14S275-tel.

The observed incidence of $\mathrm{LI}$ and CIE in Norway is $1 / 91,000$ over the last 10 years. The number of patients homozygous or compound heterozygous for the $2526 \mathrm{~A} \rightarrow \mathrm{G}$ mutation were precisely determined over the last 30 years and the corresponding gene frequency for the mutation in Norway was calculated to 0.0022 . This is slightly less than was expected (0.0033) from the observed incidence and the explanation may be due to a non-random distribution of the mutant gene.

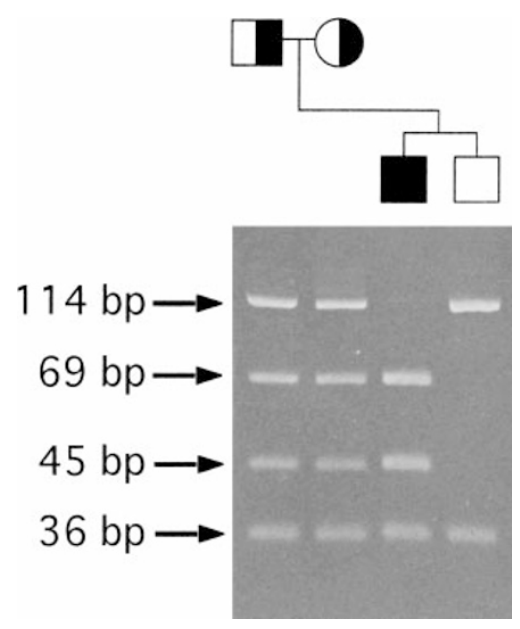

Figure 3 Detection of the $2526 \mathrm{~A} \rightarrow \mathrm{G}$ mutation by $\mathrm{Mspl}$ restriction digestion. An amplicon of $150 \mathrm{bp}$ was generated from genomic DNA in one family with one member affected by CIE. The wild type fragment includes an $\mathrm{Mspl}$ site as an internal control which results in fragments of $114 \mathrm{bp}$ and $36 \mathrm{bp}$, respectively. Accordingly, the amplicon with the A to $G$ mutation carries two restriction sites for $\mathrm{M} \mathrm{spl}$ which results in three fragments of $69 \mathrm{bp}, 45 \mathrm{bp}$ and $36 \mathrm{bp}$, respectively. L ane 1-2, parents (heterozygous); lane 3, affected son (homozygous); and lane 4, a healthy non-carrier son. 
The mutation in the splice acceptor site of intron 5 was shown to result in 876insG in the cDNA. The same $A$ to $G$ transition was previously described on genomic DNA in another family with $L I$ but with a resulting transcript that retained the complete intron 5 sequence. ${ }^{12}$ In our patients, intron 5 is indeed spliced but with only one intronic nucleotide retained. Sequencing of cDNA from six Norwegian alleles consistently showed the 876insG mutation. The reason for the different mRNAs from the same genomic alteration is unclear. We did not find the longer and non-spliced transcript in our patients but we can not exclude that it was present in low amounts. It may also have been selected against in the PCR reactions. The strong founder effect of $\mathrm{LI}$ and $\mathrm{CIE}$ in Norway in combination with a previous report of an $\mathrm{LI}$ patient

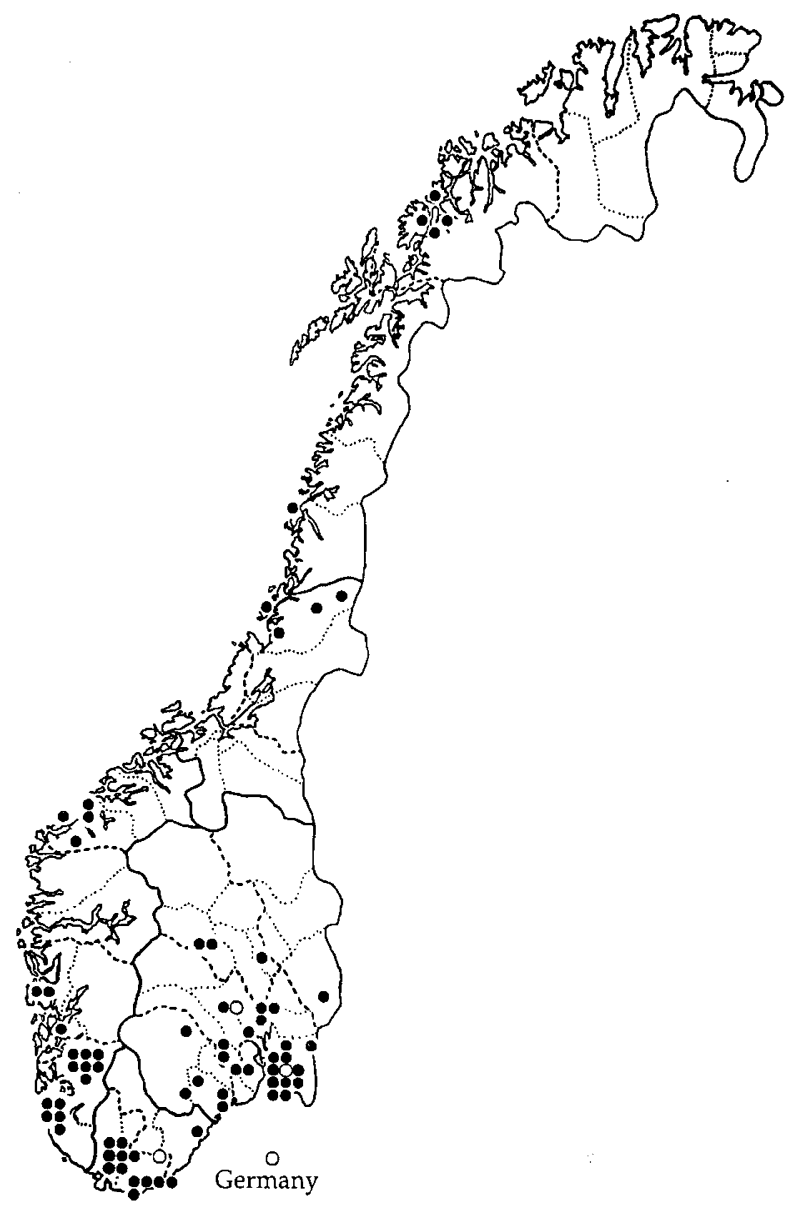

Figure $4 \mathrm{M}$ ap of N orway with parents of $\mathrm{CIE}$ and $\mathrm{LI}$ patients plotted by their place of birth (parents' residences). Filled circles: $2526 \mathrm{~A} \rightarrow \mathrm{G}$ carriers. O pen circles: carriers of allelic TG M 1 mutations according to the affected offspring which are heterozygous for the $2526 \mathrm{~A} \rightarrow \mathrm{G}$ mutation. Density of the $\mathrm{N}$ orwegian population has previously been described by $\mathrm{E}$ iken et al $1996 .^{26}$ with the same $2426 \mathrm{~A} \rightarrow \mathrm{G}$ transition suggest that other patients of E uropean descent may carry the same gene defect. This has been shown for phenylketonuria, another recessive condition in which the mutant alleles in Norway are derived from other European countries. ${ }^{26}$

The A to $\mathrm{G}$ transition was absent to two families with $\mathrm{CIE}$ and in four families with LI. The haplotypes in these families were different from the majority of haplotypes associated with the mutation but they may carry yet unknown mutations in the T GM 1 gene. In one multiplex family affected by CIE, a TGMI gene mutation is not likely since a recombination event between the phenotype and the TGM 1 intron 14 marker was seen (IR 51, Table 1 ). This also supports previous findings of genetic heterogeneity for the disorders.

Classification of the heterogenous group of autosomal recessive congenital ichthyosis has been difficult. The genetic analysis performed in this study revealed that a single mutation was responsible for the disease in the majority of cases with both $\mathrm{LI}$ and $\mathrm{CIE}$. This illustrates the importance of combining molecular analyses with clinical and ultrastructural criteria for the primary diagnosis and for the classification of congenital ichthyosis. The results presented here show that a mutation in the TGM 1 gene can result in both $L I$ and $\mathrm{CIE}$. A Ithough in some families the mutation remains unknown, the strong founder effect and an easy detection assay for the molecular defect provide an improvement for the diagnosis and for the detection of carriers in such families.

\section{Acknowledgements}

We are grateful to the families for their cooperation and to dermatologists and paediatricians for referring new families. We are indepted to Van N guyen, Lynn R ead, B irgit Carlsson, K ristina Lagerstedt, Berit M yhre D upuy, A ud G jesti, R andi Schaaning Jögensen, Per A rne A ndresen, $\mathrm{H}$ eidi Tomter Kyrkjebo, G ry G eitvik, H enrik A rnell, Jutta D eimel-H atzenbuehler, U te Schulze-H alberg, Inge Werner, B irgit K andt and Sabine Scholl for technical assistance. We thank A nders Vahlquist and G erd M ichaëlsson for discussions. The families were collected by TG -D at the Department of D ermatology, $\mathrm{R}$ ikshospitalet; the G enetic Laboratory, Institute for Cancer R esearch, The Norwegian R adium Hospital; D epartment of Medical Genetics, Regional Hospital and U niversity of Tromsö; and Institute of Forensic Medicine, U niversity of O slo. This study was supported by grants from the Swedish Medical Research Council (to ND), various funds at the $U$ ppsala $U$ niversity, the $H$ and $G A$ nkarstrands Foundation, $E$ $J$ arls and $M$ Linds Foundation, the Welander-Finsens Foundation, the Nansen Foundations, U niversity of $\mathrm{O}$ slo, A nders 
Jahres Fund, Medinnova and the Medical R esearch Council of Canada.

\section{References}

1 Williams M L and E lias PM : Heterogeneity in autosomal recessive ichthyosis. Clinical and biochemical differentiation of lamellar ichthyosis and nonbullous congenital ichthyosiform erythroderma. A rch Dermatol 1985; 121: 47-88.

2 Williams ML, Elias PM: Disorders of cornification. In: A lper JL (ed). Dermatologic Clinics. Saunders: Philadelphia, 1987; 155-178.

3 Traupe $\mathrm{H}$ : The ichthyoses. A guide to clinical diagnosis, genetic counseling, and therapy. Springer: Heidelberg, 1989; pp 111-134.

4 Williams ML: Ichthyosis: mechanisms of disease. Pediatr D ermatol 1992; 9: 365-368.

5 Niemi K M, K anerva L, Kuokkanen K, I gnatius ] : Clinical, light and electron microscopic features of recessive congenital ichthyosis type I. Br J Dermatol 1994; 130: 626-633.

6 A rnold $M-L$, A nton- $L$ amprecht I, M elz- $R$ othfuss $B, H$ artschuh W: Ichthyosis congenita type III. Clinical and ultrastructural characteristics and distinction within the heterogeneous ichthyosis group. A rch D ermatol Res, 1988; 280: 268-278.

7 A nton-Lamprecht I: The Skin. In: Papadimitriou JM, Henderson DW, Spagnolo DV (eds). Diagnostic Ultrastructure of Non-neoplastic D iseases. Churchill Livingstone: E dinburgh, 1992; pp 459-550.

8 R ussell LJ, D i G iovanna J J, H ashem N, Compton J G, Bale S) : L inkage of autosomal recessive lamellar ichthyosis to chromosome 14q. A m J H um G enet 1994; 55: 1146-1152.

9 Palowska RR, Eddy $R L$, Shows TB, Goldsmith $L A$ : E pidermal type I transglutaminase (TG M 1 ) is assigned to human chromosome 14. Cytogenet Cell Genet, 1991; 56: 105-107.

$10 \mathrm{Kim} \mathrm{I-G,} \mathrm{McBride} \mathrm{OW,} \mathrm{Wang} M, K$ im S-Y, Idler WW, Steinert PM: Structure and organization of the human transglutaminase 1 gene. I Biol Chem 1992; 267: 7710-7717.

11 Yamanishi K, Inazawa J, L iew F-M et al: Structure of the gene for human transglutaminase 1. J Biol Chem, 1992; 267: 17858-17863.

12 Huber M, Rettler I, Bernasconi $K$ et al: Mutations of keratinocyte transglutaminase in lamellar ichthyosis. Science 1995; 267: 525-528.

13 R ussell LJ, DiGiovanna JJ, Rogers GR, Hashem N, Compton JG, Bale SJ: M utations in the gene for transglutaminase 1 in autosomal recessive lamellar ichthyosis. Nat G enet 1995; 9: 279-283.
14 Parmentier L, Blanchet-Bardon C, N guyen S, Prud'homme J-F, D ubertret L, Weissenbach J: A utosomal recessive lamellar ichthyosis: identification of a new mutation in transglutaminase 1 and evidence for genetic heterogeneity. Hum M ol G enet 1995; 4: 1391-1395.

$15 \mathrm{H}$ uber $\mathrm{M}, \mathrm{Y}$ ee $\mathrm{VC}$, Burri $\mathrm{N}$ et al: Consequences of seven novel mutations on the expression and structure of keratinocyte transglutaminase. J Biol Chem 1997; 272: 21018-21026.

16 Laiho $\mathrm{E}$, I gnatius J, M ikkola $\mathrm{H}$ et al: Transglutaminase 1 mutations in autosomal recessive congenital ichthyosis: private and recurrent mutations in an isolated population. A m J H um G enet 1997; 61: 529-538.

17 Bichakjian CK, Nair R P, Welby WW, Goldberg S and EIder JT: Prenatal exclusion of lamellar ichthyosis based on identification of two new mutations in the transglutaminase 1 gene. J Invest Dermatol 1998; 110: 179-182.

18 Huber M, R ettler I, Bernasconi K, Wyss $M$ and $\mathrm{H}$ ohl D: Lamellar ichthyosis is genetically heterogeneous - cases with normal keratinocyte transglutaminase. J Invest Dermatol 1995; 105: 653-654.

19 Parmentier L, Lakhdar H, Blanchet-B ardon C, M archand $S$, D ubertret $L$, Weissenbach $J$ : $M$ apping of a second locus for lamellar ichthyosis to chromosome 2q33-35. $\mathrm{H}$ um M ol G enet 1996; 5: 555-559.

20 Sambrook J, Fritsch E F, M aniatis T: M olecular cloning: a Laboratory Manual. New York: Cold Spring Harbor L aboratory Press, 1989.

21 Miller SA, Dykes DD, Polesky HF: A simple salting out procedure for extracting DNA from human nucleated cells. Nucleic A cids Res 1988; 16: 1215-1215.

22 Dib C, Fauré S, Fizames $C$ et al: A comprehensive genetic map of the human genome based on 5264 microsatellites. Nature. 1996; 380: 152-154.

23 Pigg $M$, Jagell S, Sillén A, Weissenbach J, G ustavson K - H Wadelius $C$ : The Sjögren- $L$ arsson syndrome gene is located close to D17S805 as determined by linkage analysis and allelic association. Nat Genet 1994; 8: 361-364.

24 Dupuy BM, Olaisen B: A dedicated internal standard in fragment length analysis of hyperpolymorphic short tandem repeats. Forensic Sci Int 1997; 86: 207-227.

25 Chomczynski P, Sacchi N : Single-step method of RNA isolation by acid guanidinium thiocyanate-phenol-chloroform extraction. A nal Biochem 1987; 162: 156-159.

26 Eiken HG, K nappskog PM, Boman $H$ et al: Relative frequency, heterogeneity and geographic clustering of PKU mutations in Norway. Eur J H um Genet 1996; 4: 205-213. 